\title{
Hubungan Pengetahuan Ibu Dengan Kejadian Stunting Pada Balita Umur 12-59 Bulan
}

\author{
${ }^{1}$ Jumiarsih Purnama AL \\ ${ }^{2}$ Indirwan Hasanuddin \\ ${ }^{3}$ Sulaeman $S$
}

1,2,3 Ilmu Keperawatan STIKES Muhammadiyah Sidrap

\begin{abstract}
Alamat Korespondensi:
Jumiarsih Purnama AL

Program Studi Ilmu Keperawatan

Sekolah Tinggi Ilmu Kesehatan Muhammadiyah Sidrap

Hp. 082198691517

Email: jumiarsihpurnama91@yahoo.com
\end{abstract}




\begin{abstract}
ABSTRAK
Stunting adalah gangguan kronik akibat kurangnya gizi sehingga menghambat pertumbuhan dan perkembangan pada bayi. Stunting adalah kondisi dimana terjadinya suatu gangguan pertumbuhan fisik yang ditandai dengan pertumbuhan yang tidak optimal sebagai akibat dari ketidak seimbangan gizi (Apriluana \& Fikawati, 2018). Stunting masih menjadi permasalahan besar untuk sebagian besar negara di dunia. Penelitian ini bertujuan untuk mengetahui hubungan pengetahuan ibu dengan kejadian stunting pada balita usia 12-59 bulan di wilayah kerja Puskesmas Lawawoi Kabupaten Sidrap. Jenis penelitian yang digunakan adalah penelitian deskriptif analitik dengan pendekatan cross sectional studi. Sampel dalam penelitian adalah 30 responden dengan teknik penarikan sampel Purposive sampling. Data hasil penelitian dianalisis dengan menggunakan uji chi square. Hasil penelitian diperoleh bahwa ada hubungan antara pengetahuan ibu dengan kejadian stunting dengan nilai $\mathrm{p}=0,02(\mathrm{p}<\alpha=$ 0,05) pada balita usia 12-59 bulan di wilayah kerja Puskesmas Lawawoi Kabupaten Sidrap.
\end{abstract}

\title{
Kata Kunci : Pengetahuan Ibu, Stunting, Balita
}

\begin{abstract}
Stunting is a chronic disorder caused by a lack of nutrition that hinders growth and development in infants. Stunting is a condition in which there is a physical growth disorder characterized by suboptimal growth as a result of nutritional imbalances (Apriluana \& Fikawati, 2018). Stunting is still a big problem for most countries in the world. This study aims to determine the relationship between maternal knowledge and the incidence of stunting in infants aged 12-59 months in the working area of Puskesmas Lawawoi, Sidrap Regency. This type of research is a descriptive analytic study with a cross sectional study approach. The sample in this study was 30 respondents with purposive sampling technique. The research data were analyzed using the chi square test. The results showed that there was a relationship between maternal knowledge and the incidence of stunting with a value of $p=0.02(p<\alpha=0.05)$ in children aged 12-59 months in the working area of Puskesmas Lawawoi, Sidrap Regency.
\end{abstract}

Keywords: Mother's Knowledge, Stunting, Toddler 


\section{PENDAHULUAN}

Stunting adalah gangguan kronik akibat kurangnya gizi sehingga menghambat pertumbuhan dan perkembangan pada bayi. Stunting adalah kondisi dimana terjadinya suatu gangguan pertumbuhan fisik yang ditandai dengan pertumbuhan yang tidak optimal sebagai akibat dari ketidak seimbangan gizi (Apriluana \& Fikawati, 2018).

Menurut data WHO (2016) terdapat 162 juta balita penderita stunting di seluruh dunia, dimana $56 \%$ berasal dari Asia. Dibandingkan beberapa Negara tetangga, prevalensi balita pendek di Indonesia juga tertinggi dibandingkan Msyanmar (35\%), Vietnam (23\%), Malaysia (17\%), Thailand (16\%), dan Singapura (4\%). Global Nutrition Report tahun 2014 menunjukkan Indonesia termasuk dalam 17 negara, diantara 117 negara yang mempunyai 3 masalah gizi yaitu stunting.

Prevalensi stunting secara Nasional pada tahun 2013 sejumlah 37,2 \%. Pemantauan status gizi tahun 2016 mencapai 27,5 \%, melebihi batas $\mathrm{WHO}$ $<20 \%$. Hal ini berarti pertumbuhan yang tidak maksimal dialami oleh sekitar 8,9 juta anak Indonesia, atau 1 dari 3 anak Indonesia mengalami stunting. Lebih dari 1/3 anak berusia di bawah 5 tahun di Indonesia tingginya berada di bawah ratarata (Sandjojo \& Majid, 2017).
Data stunting di Provinsi Sulawesi Selatan pada tahun 2010 justru lebih tinggi dari pada angka nasional yakni 38,9\% dan tahun 2013 prevalensi balita stunting di Sulawesi Selatan meningkat kembali menjadi $41 \%$. Hal ini menandakan bahwa prevalensi stunting pada balita merupakan masalah kesehatan masyarakat yang serius karena mencapai prevalensi stunting $>40 \%$ (RISKESDAS, 2013 dalam Irviani dkk, 2014).

Berdasarkan data Dinas Kesehatan Kabupaten Sidrap tahun 2017, wilayah dengan prevalensi tertinggi stuntingadalah di wilayah kerja Puskesmas Lawawoi 1005 balita (32,89\%), Pangkajene 464 balita (10,69\%), Puskesmas Empagae 328 balita (20,10\%) (Dinkes Kab. Sidrap, 2017).

Berdasarkan data dari dinas kesehatan kabupaten sidrap, wilayah dengan jumlah kejadian balita stunting tertinggi adalah daerah lawawoi dengan jumlah 363 orang yang merupakan balita umur 12-59 bulan yang terdiri dari 196 orag laki-laki dan 167 orang perempuan. Data tersebut di peroleh dari data jumlah stunting wilayah kerja puskesmas lawawoi, dengan desa/kelurahan arawa 40 orang, bangkai 25 orang, batulappa 38 orang, buae 56 orang, carawali 29 orang, cirociroe 18 orang, lainungan 47 orang, lawawoi 33 orang, mattirotasi 21 orang, uluale 56 orang. (Dinkes Kab. Sidrap, 2019) 
Dari latar belakang dan studi pendahuluan di atas maka perlu dilakukan penelitian tentang "Hubungan Pengetahuan Ibu Dengan Kejadian Stunting Pada Balita Umur 12-59 Bulan”.

Berdasarkan penelitian yang dilakukan oleh Pormes dkk, (2014) tentang "Hubungan pengetahuan orang tua tentang gizi dengan stunting pada anak usia 4-5 tahun di TK Malaekat Pelindung Manado”. Hasil penelitian menunjukkan bahwa dari 30 anak, 24 diantaranya memiliki (TB/U) normal (96\%) disertai dengan pengetahuan orang tua tentang gizi yang baik, ada 1 anak yang memiliki tinggi badan normal (TB/U) tetapi memiliki pengetahuan orang tua tentang gizi yang tidak baik (4\%), sedangkan 5 anak denga stunting memiliki orang tua dengan pengetahuan tentang gizi yang tidak baik (100\%).

Tujuan dari penelitian ini adalah untukmengidentifikasi hubungan antara pengetahuan ibu dengan kejadian stunting pada balita umur 12-59 bulan.

\section{METODE}

Desain penelitian pada penelitian ini adalah penelitian kuantitatif dengan desain deskriptif analitik menggunakan pendekatan cross sectional, dimana pengumpulan data dan pengukuran variabel independen dan variabel dependen dilakukan pada waktu yang bersamaan (Amalia Amanda, 2014).
Populasi adalah keseluruhan jumlah anggota dari suatu himpunan yang ingin diketahui karakteristiknya berdasarkan inferensi atau generalisasi (Supardi \& Rustika, 2014). Populasi dalam penelitian ini adalah Ibu yang mempunyai anak stuntingdi Wilayah Kerja Puskesmas Lawawoi Kabupaten Sidrap yang berjumlah 363 orang.

Teknik pengambilan sampel yang digunakan pada penelitian ini adalah Purposive sampling yaitu cara pengambilan sampel berdasarkan kriteria yang ditentukan oleh peneliti untuk dapat dianggap mewakili karakteristik populasinya adapun besar sampel sebanyak 30 responden di wilayah kerja Puskesmas lawawoi (Supardi \& Rustika, 2014). Dalam pemilihan sampel peneliti membuat kriteria inklusi dan kriteria eksklusi. Subyek yang memenuhi kriteria inklusi akan masuk dalam sampel penelitian sedangkan subyek yang memenuhi kriteria eksklusi maka subyek tidak masuk dalam sampel penelitian.

Pengumpulan data yang digunakan dalam penelitian ini adalah Angket (Quesioner) merupakan cara pengumpulan data penelitian dengan mengirimkan atau memberikan kuesioner kepada responden untuk mengisinya sendiri, angket memerlukan pedoman pengisian agar memudahkan responden mengisi dan mencegah terjadi kesalahan interpretasi 
pertanyaan (Supardi \& Rustika, 2014). Angket ini bersifat tertutup dan digunakan untuk mengukur variabel pengetahuan orang tua.

Pengukuran merupakan cara pengumpulan data penelitian dengan mengukur objek menggunakan alat ukut tertentu (Supardi \& Rustika, 2014). Pengukuran digunakan untuk mengukur tinggi badan anak.

Data yang sudah diolah kemudian dianalisa dengan menggunakan menggunakan program computer yang meliputi Analisa univariat yang dilakukan untuk mengetahui karakteristik data demografi, masing-masing variable yaitu variable independen (Pengetahuan seorang ibu) dan variable dependen (Kejadian Stunting). Dan Analisis Bivariat dilakukan dengan uji chi square yang digunakan untuk menguji hipotesis hubungan pengetahuan seorang ibu dengan kejadian stunting pada anak di wilayah kerja Puskesmas Lawawoi

\section{HASIL}

Berdasarkan tabel 1 menunjukkan bahwa dari 30 orang, yang tergolong umur Ibu 20-25 tahun sebanyak 7 orang (23\%), umur 26-30 tahun sebanyak 8 orang (27\%), umur 31-35 tahun sebanyak 4 orang (13\%), dan >35 sebanyak 11 orang (37\%). Sebanyak 19 orang ibu (63\%) berumur <35 tahun. Berdasarkan pendidikan menunjukkan bahwa dari 30 orang ibu balita, yang tergolong pendidikan SD sebanyak 13 orang (43\%), pendidikan SMP sebanyak 11 orang (37\%), dan pendidikan SMA sebanyak 6 orang (20\%). Berdasarkan jumlah anggota keluarga menunjukkan bahwa dari 30 orang, yang tergolong 2 anggota keluarga sebanyak 0 orang (0\%), 3 anggota keluarga sebanyak 8 orang (27\%), >4 anggota keluarga sebanyak 22 orang (73\%). Berdasarkan jenis kelamin menunjukkan bahwa dari 30orang dalam penelitian ini laki-laki sebanyak 12 orang (40\%) dan perempuan 18 orang $(60 \%)$. Berdasarkan Umur Balita menunjukkan bahwa dari 30orang, yang tergolong umur 12-24 bulan sebanyak 1 orang (3\%), umur 25-36 bulan sebanyak 8 orang (27\%), umur 37-59bulan sebanyak 21 orang $(70 \%)$.

Berdasarkan tabel 2 menunjukkan bahwa dari 30 orang yang diteliti terdapat 9 ibu balita yang memiliki pengetahuan baik (30\%) dan 21 ibu balita yang memiliki pengetahuan kurang (70\%). Berdasarkan balita stunting menunjukkan bahwa dari 30 orang yang diteliti yang masuk dalam kategori pendek sebanyak 10 orang (33\%), sedangkan responden dengan kategori sangat pendek sebanyak 20 orang $(67 \%)$.

Berdasarkan tabel 3 diperoleh data bahwa dari 30 ibu balita dengan pengetahuan ibu yang baik dengan kejadian stunting pada anak usia 12-59 
bulan yang masuk kategori pendek sejumlah 7 orang (23\%) dan pengetahuan ibu yang kurang dengan kejadian stunting pada anak usia 12-59 bulan berjumlah 3 orang dengan kategori pendek (10\%), sedangkan pengetahuan ibu yang baik dengan kejadian stunting pada anak usia 12-59 bulan yang masuk kategori sangat pendek jumlah 2 orang $(7 \%)$, dan pengetahuan ibu yang kurangjumlah 18(70\%). Total yang memiliki pengetahuan yang baik sejumlah 9 orang (30\%) dan total yang memiliki pengetahuan yang kurang sejumlah 21 orang $(70 \%)$, sedangkan total anak masuk kategori pendek sejumlah 10 orang (33\%) dan total anak masuk kategori sangat pendek sejumlah 20 orang (77\%). sehingga total secara keseluruhan sejumlah 30 orang (100\%).

Dari hasil uji Chi Square didapatkan nilai $\mathrm{p}=0,02$ lebih kecil dari nilai $\alpha(0,05)$ maka dapat disimpulkan bahwa H0 ditolak dan Ha diterima, yang artinya ada hubungan antara pengetahuan ibu terhadap kejadian stunting pada anak usia 12-59 bulan di wilayah kerja Puskesmas Lawawoi Kabupaten Sidrap Tahun 2020.

\section{PEMBAHASAN}

Berdasarkan analisis hasil penelitian ternyata dari $30 \mathrm{ibu}$ dengan pengetahuan kategori pendek sebanyak 10 0rang (33\%), sedangkan ibu dengan kategori baik tujuh orang (23\%), sedangkan ibu dengan kategori pengetahuan kurang, kejadian stunting pada balitanya dengan kategori pendek sebanyank tiga orang (10\%). Selanjutnya, ibu dengan kategori pengetahuan baik, kejadian stuntingpada balitanya dengan kategori sangat pendek sebanyak dua orang (27\%), sedangkan ibu dengan pengetahuan kategori kuang sebanyak 18 orang (70\%), kejadian stunting pada balitanya dengan kategori sangat pendek, sehingga total secara keseluruhan sejumlah 30 orang (100\%). Di dapatkan hasil penelitian ini menggunakan uji chi-square dan nilai diperoleh adalah $p$ $=0,02$. Hal ini berate nilai $p$ lebih kecil dari $\alpha(0.05)$.

Hasil penelitian ini sejalan dengan penelitian Pormes dkk, (2014), tentang "Hubungan pengetahuan orang tua tentang gizi dengan stunting pada anak usia 4-5 tahun di TK Malaekat Pelindung Manado". Didapatkan hasil penelitian ini menggunakan uji chi-square dan nilai yang diperoleh ialah $p=0,000$. Hal ini berarti nilai $p$ lebih kecil dari $\alpha(0.05)$. karena nilai $p<0,05$, maka dengan demikian dapat ditarik kesimpulan bahwa H0 ditolak. Sehingga dapat dikatakan bahwa ada hubungan yang bermakna antara pengetahuan orang tua tentang gizi dengan stunting pada anak usia 4-5 tahun di TK Malaekat Pelindung Manado $(p=0,000)$.

Dari hal di atas peneliti berasumsi bahwa pengetahuan ibu berpengaruh 
terhadap kejadian stunting pada anak usia 12-59 bulan. Pengetahuan orang tua dapat membantu memperbaiki status gizi pada anak untuk mencapai kematangan pertumbuhan. Pengetahuan yang tidak memadai, kurangnya pengertian tentang kebiasaan makan yang baik, serta pengertian yang kurang mengenai stunting menentukan sikap dan perilaku ibu dalam menyediakan makanan untuk anaknya termasuk jenis dan jumlah yang tepat agar anak dapat timbuh dan berkembang secara optimal.

Sehingga dapat disimpulkan bahwa hasil penelitian ini menunjukkan bahwa kejadian stunting pada anak usia 12-59 bulan di Wilayah Kerja Puskesmas Lawawoi Kabupaten Sidrap tahun 2020, baik itu pendek maupun sangat pendek, lebih banyak terjadi pada ibu yang berpengetahuan kurang. Semakin tinggi pengetahuan ibu tentang stunting dan kesehatan maka penilaian makanan semakin baik, sedangakan pada keluarga yang pengetahuannya rendah seringkali anak makan dengan tidak memenuhi kebutuhan gizi.

\section{KESIMPULAN DAN SARAN}

Berdasarkan analisis hasil penelitian maka dapat ditarik kesimpulan bahwa ada hubungan antara pengetahuan ibu dan kejadian stunting pada balita usia 12-59 bulan di wilayah kerja Puskesmas
Lawawoi Kabupaten Sidrap,dengan nilai $\mathrm{p}=0,02$ Oleh karena $\mathrm{p} 0,02<0,05(\alpha)$.

Berdasarkan hasil penelitian maka dapat diberikan beberapa saran kepada pihak yang terkait hendaknya selalu memantau pertumbuhan dan perkembangan sejak bayi dalam kandungan secara rutin agar agar tumbuh secara optimal dan mampu menjadi keluarga kadar gizi (kadarzi), sehingga masalah gizi kronis dapat ditanggulangi. Tingginya prevalensi kekurangan gizi berdasarkan indeks gabungan (CIAF), maka selayaknya jika penilaian status gizi balita berdasarkan metode ini dapat dipertimbangkan dan di terapkan, agar dapat memperkirakan prevalensi kekurangan gizi secara komprehensif sehingga bermanfaat bagi perencana program dan intervensi yang di lakukan dapat tepat sasaran.

Melakukan pemantauan pertumbuhan balita di posyandu, memberikan penyuluhan dan konseling menyusui dan Makanan Pendamping ASI (MP ASI) serta Pemberian Makanan Tambahan (PMT) pemulihan yang aman, bemutu dan berbasis bahan makanan local pada balita yang mengalami masalah gizi CIAF untuk mencukupi kebutuhan gizi balita.

Perlunya pendidikan dan pelatihan secara khusus bagi petugas kesehatan dan kader posyandu dalam melakukan 
pengukuran antropometri secara benar, sehingga di dapatkan prevalensi status gizi balita yang valid dan reliabel. Diperlukan kerjasama dan dukungan dari stakeholder (lintas sector) dalam pemberdayaan masyarakat untuk memperbaiki pola asuh dan upaya peningkatan pengetahuan ibu tentang pola gizi seimbang serta peningkatan kunjungan ke posyandu pada meja 4 dan 5.

Diharapkan agar penelitian ini dapat menjadi sumber informasi sehingga dapat lebih mempehatikan pemberian penyuluhan kepada masyarakat, dan juga diharapkan dapat menjadi sumber informasi bagi masyarakan terutama pada ibu yang memiliki balita stunting sehingga lebih dapat meningkatkan pengetahuan dan kesadaran akan kesehatan serta dapat bersikap positif terhadap segala sesuatu yang berkaitan dengan penyakit stunting.

\section{DAFTAR PUSTAKA (REFERENSI)}

Amalia Amanda. (2014). Hubungan asupan zat gizi (energi, protein besi, dan seng), stunting dan stimulasi psikososial dengan status motorik anak usia 3-6 tahundi paud wilayah binaan puskesmas kecematan kebayoran lama tahun 2014.

Apriluana, G., \& Fikawati, S. (2018). Analisis Faktor-Faktor Risiko terhadap Kejadian Stunting pada Balita (0-59 Bulan) di Negara Berkembang dan Asia Tenggara. Media Penelitian Dan Pengembangan Kesehatan, 28(4), 247-256. https://doi.org/10.22435/mpk.v28i4.4 72

Bertalina, B., \& P.R, A. (2018). Hubungan
Asupan Gizi, Pemberian Asi Eksklusif, dan Pengetahuan Ibu dengan Status Gizi (Tb/U) Balita 6-59 Bulan. Jurnal Kesehatan, 9 (1), 117. https://doi.org/10.26630/jk.v9i1.800

Chamidah, A. N. (2009). Deteksi dini gangguan pertumbuhan dan perkembangn anak. Pendidikan Khusus, 5, 2.

Chamidah, A. N., \& Yogyakarta, U. N. (2012). Deteksi Dini Gangguan Pertumbuhan dan Perkembangan Anak. JPK (Jurnal Pendidikan Khusus), 4(3). https://doi.org/10.21831/jpk.v4i3.789

Irviani A., Ibrahim, \& Ratih F. (2014). Hubungan Faktor Sosial Ekonomi Keluarga dengan Kejadian Stunting Anak Usia 24-59 Bulan di Wilayah Kerja Puskesmas Barombong.

Kemendes. (2017). Buku saku desa dalam penanganan stunting. Buku Saku Desa Dalam Penanganan Stunting, 42. Retrieved from https://siha.depkes.go.id

Notoadmodjo, \& soekidjo. (2010). promosi kesehatan dan perilaku kesehatan.

Nursalam. (2008). konsep dan penerapan metodologi penelitian ilmu keperawatan.

Olsa, E. D., Sulastri, D., \& Anas, E. (2017). Hubungan Sikap dan Pengetahuan Ibu Terhadap Kejadian Stunting pada Anak Baru Masuk Sekolah Dasar di Kecamanatan Nanggalo. Jurnal Kesehatan Andalas, 6(3), 523-529. Retrieved from http://jurnal.fk.unand.ac.id/index.php/ $\mathrm{jka} /$ article/view/733

Pormes, W., Rompas, S., \& Ismanto, A. (2014).

HUBUNGAN PENGETAHUAN ORANG TUA TENTANG GIZI DENGAN STUNTING PADA ANAK USIA 4-5 TAHUN DI TK MALAEKAT PELINDUNG MANADO. Jurnal Keperawatan UNSRAT, 2(2), 105260.

Pos, K., \& Gorontalo, K. (2017). HUBUNGAN PENGETAHUAN GIZI IBU DENGAN KEJADIAN 


\section{STUNTING}

Rahim, A. ., \& Pratiwi, R. (2017). hubungan komsumsi ikan terhadap kejadian stunting pada anak usia 2-5 tahun. Kedokteran Diponegoro, 6, 1 .

Sandjojo, E. putro. (2017). Buku saku desa dalam penanganan stunting. Buku Saku Desa Dalam Penanganan Stunting.

Saragih, s, Jumaini, \& Indriati, g. (2013). gambaran tingkat pengetahuan dan sikap keluarga tentang perawatan pasien resiko perilaku kekerasan di rumah.

Saragih S, Sumaini, \& Indrianti, G. (2016). gambaran tingkat pengetahuan dan sikap keluarga tentang perawatan pasien resiko perilaku kekerasan di rumah.

Sembiring, J. . (2017). asuhan neonatus, bayi, balita, anak pra sekolah.

Supardi, s, \& Rustika. (2014).

metodologi riset keperawatan. 
Tabel 1. Distribusi frekuensi Berdasarkan Umur, Pendidikan, Jumlah Anggota Keluarga dan Distribusi frekuensi Balita Berdasarkan Jenis Kelamin, Umur

\begin{tabular}{|c|c|c|}
\hline Karakteristik Responden & Frekuensi (f) & Persentase $(\%)$ \\
\hline Umur Ibu & f & $\%$ \\
\hline Umur 20-25 tahun & 7 & 23 \\
\hline Umur 26-30 tahun & 8 & 27 \\
\hline Umur 31-35 tahun & 4 & 13 \\
\hline Umur $>30$ tahun & 11 & 37 \\
\hline Pendidikan Ibu & $\mathbf{f}$ & $\%$ \\
\hline $\mathrm{SD}$ & 13 & 43 \\
\hline SMP & 11 & 37 \\
\hline SMA & 6 & 20 \\
\hline Jumlah Anggota Keluarga & $\mathbf{f}$ & $\%$ \\
\hline 3 & 0 & 0 \\
\hline 3 & 8 & 27 \\
\hline$>4$ & 22 & 73 \\
\hline Jenis Kelamin Balita & $\mathbf{f}$ & $\%$ \\
\hline Perempuan & 18 & 60 \\
\hline Laki-laki & 12 & 40 \\
\hline Umur Balita & $\mathbf{f}$ & $\%$ \\
\hline Umur $12-24$ bulan & 1 & 3 \\
\hline Umur 25-36 bulan & 8 & 27 \\
\hline Umur 37-59 bulan & 21 & 70 \\
\hline Total & 30 & 100 \\
\hline
\end{tabular}


Tabel 2. Distribusi Ibu Balita Berdasarkan Pengetahuan dan Distribusi Balita Berdasarkan Klasifikasi stunting

\begin{tabular}{ccc}
\hline Karakteristik Responden & Frekuensi (f) & Persentase (\%) \\
\hline Pengetahuan Ibu & $\mathbf{f}$ & \% \\
\hline Baik & 9 & 30 \\
Kurang & 21 & 70 \\
\hline Total & $\mathbf{3 0}$ & $\mathbf{1 0 0}$ \\
\hline Balita Stunting & $\mathbf{f}$ & $\mathbf{\%}$ \\
\hline Pendek & 10 & 33 \\
Sangat Pendek & 20 & 67 \\
\hline Total & $\mathbf{3 0}$ & $\mathbf{1 0 0}$ \\
\hline
\end{tabular}

Tabel 3. Hubungan antara Pengetahuan ibudan kejadian stunting pada Balita usia 12-59 bulan

\begin{tabular}{ccccccccc}
\hline & \multicolumn{9}{c}{ Stunting } & & \\
\cline { 2 - 6 } Pengetahuan orang tua & Pendek & $\%$ & $\begin{array}{c}\text { Sangat } \\
\text { pendek }\end{array}$ & $\%$ & Total & $\%$ & P Value \\
\cline { 2 - 7 } & 7 & 23 & 2 & 7 & 9 & 30 & \\
\hline Baik & 3 & 10 & 18 & 70 & 21 & 70 & 0,02 \\
\hline Kurang & $\mathbf{1 0}$ & $\mathbf{3 3}$ & $\mathbf{2 0}$ & $\mathbf{7 7}$ & $\mathbf{3 0}$ & $\mathbf{1 0 0}$ & \\
\hline
\end{tabular}

